\title{
Evaluasi Perencanaan Umum Pengadaan Barang/ Jasa Pemerintah pada Universitas Brawijaya
}

\author{
Arif Hidayat ${ }^{\mathrm{a}} *$ \\ ${ }^{a}$ Universitas Brawijaya, Malang, Jawa Timur, Indonesia
}

\section{INFORMASI ARTIKEL}

\section{Article history:}

Dikirim tanggal: 26 Maret 2019

Revisi pertama tanggal: 10 April 2019

Diterima tanggal: 22 April 2019

Tersedia online tanggal: 30 April 2019

Keywords: procurement, the procurement plan, Brawijaya University

\begin{abstract}
The success of the procurement is influenced by the planning of procurement that are well contained in the procurement plan. From the procurement history in Universitas Brawijaya it is known that there is a gap between planning and implementing procurement. This study aims to uncover and evaluate problems related to procurement planning in the University of Brawijaya environment while providing solutions to overcome these problems. Problems were revealed through in-depth interviews with procurement management officials. There are four sources of problems related to the procurement plan. Universitas Brawijaya leaders must give more intense attention to the procurement planning process so that these problems can be reduced
\end{abstract}

\section{INTISARI}

Keberhasilan pelaksanaan pengadaan barang/ jasa dipengaruhi oleh perencanaan pengadaan barang/jasa yang baik, yang tertuang dalam rencana umum pengadaan. Dari riwayat pengadaan di Universitas Brawijaya diketahui terdapat gap antara perencanaan dengan pelaksanaan pengadaan. Penelitian ini bertujuan untuk mengungkap dan mengevaluasi permasalahan terkait perencanaan pengadaan di lingkungan Universitas Brawijaya sekaligus memberikan solusi untuk mengatasi permasalahan tersebut. Permasalahan diungkap melalui wawancara mendalam dengan para pejabat pengelola pengadaan. Terdapat empat sumber permasalahan berkaitan dengan rencana umum pengadaan. Pimpinan Universitas Brawijaya harus memberikan perhatian yang lebih intens terhadap proses perencanaan umum pengadaan agar permasalahan tersebut dapat direduksi.

2019 FIA UB. All rights reserved.

\section{Pendahuluan}

Peningkatan kualitas pelayanan publik melalui penyelenggaraan tata pemerintahan yang baik dan bersih perlu didukung pengelolaan keuangan yang efektif, efisien, transparan, dan akuntabel. Untuk meningkatkan efisiensi dan efektifitas penggunaan keuangan negara yang dibelanjakan melalui proses pengadaan barang/ jasa pemerintah, diperlukan upaya menciptakan keterbukaan, transparansi, akuntabilitas serta persaingan yang sehat dalam proses pengadaan barang/ jasa pemerintah. Melalui upaya tersebut dapat diperoleh barang/ jasa yang terjangkau dan berkualitas serta dapat dipertanggungjawabkan baik dari segi fisik, keuangan, maupun manfaatnya bagi kelancaran tugas pemerintah dan pelayanan masyarakat. 
Upaya tersebut juga telah dilaksanakan oleh Universitas Brawijaya sebagai satuan kerja (Satker) Kementerian Riset, Teknologi, dan Pendidikan Tinggi. Hal ini ditunjukkan dari data yang dihimpun dari laman http://lpse.ub.ac.id/, bahwa sejak Tahun 2011 Universitas Brawijaya telah melaksanakan pengadaan barang/ jasa melalui proses lelang secara elektronik. Rata-rata nilai paket pengadaan yang dilaksanakan di Universitas Brawijaya mencapai kurang lebih $30 \%$ dari total anggaran belanja. Hal ini menunjukkan bahwa belanja barang dan jasa merupakan bagian yang sangat penting dari realisasi anggaran belanja Universitas Brawijaya. Untuk memberikan gambaran perbandingan antara total nilai pengadaan dengan total anggaran belanja Universitas Brawijaya dari Tahun 2011 hingga Tahun 2015 disajikan infografis sebagai berikut:

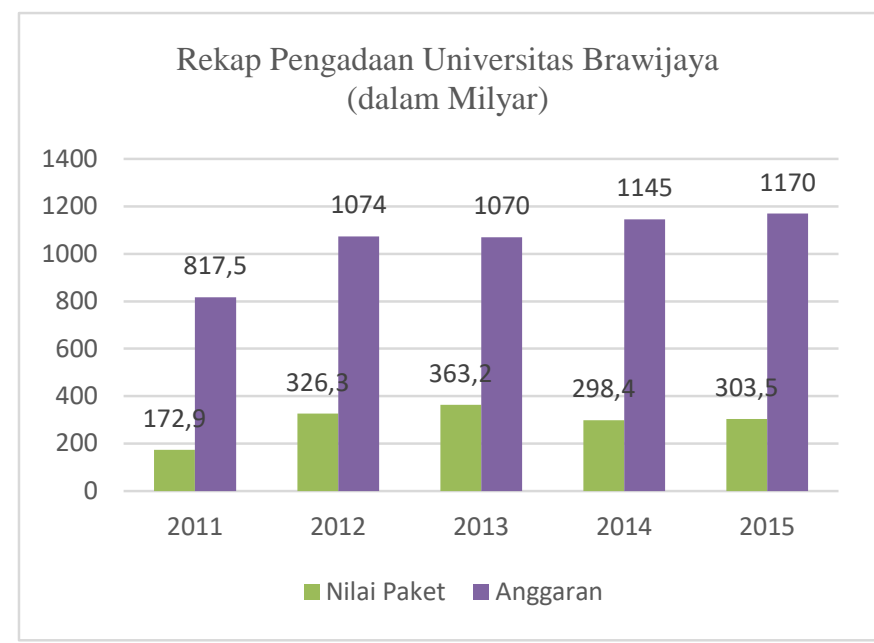

Gambar 1 Rekap Pengadaan Universitas Brawijaya (dalam Milyar)

Sumber: Hasil analisis, 2018

Peraturan Presiden Nomor 54 Tahun 2010 tentang Pengadaan Barang/ Jasa Pemerintah pasal 1 menyebutkan pengertian dari Pengadaan Barang/ Jasa Pemerintah sebagai kegiatan untuk memperoleh barang/ jasa oleh institusi pemerintah yang prosesnya dimulai dari perencanaan kebutuhan sampai diselesaikannya seluruh kegiatan untuk memperoleh barang/ jasa. Perencanaan merupakan tahapan yang penting dalam siklus manajemen. Deming, W. Edwards (1986) menyebutkan ada empat tahapan dalam siklus manajemen, yaitu Plan (merencanakan), Do (melaksanakan), Check (memeriksa), Act (menindaklanjuti) atau biasa dikenal sebagai siklus PDCA. Penerapan PDCA dalam pengadaan barang/ jasa pemerintah dapat dijelaskan melalui siklus pengadaan barang/ jasa sebagaimana dijelaskan dalam Perpres 54 Tahun 2010.

Siklus pengadaan barang/ jasa pemerintah dimulai dari tahapan perencanaan umum pengadaan, selanjutnya dilaksanakan proses pengadaan barang/ jasa yang pada prinsipnya menggunakan metode pelelangan umum sampai dengan diserahterimakannya barang/ jasa. Siklus tersebut merupakan satu kesatuan tahapan yang tidak bisa dipisahkan antara tahapan satu dengan tahapan lainnya. Proses pengadaan barang/ jasa yang tidak didahului perencanaan atau perencanaan yang tidak dilanjutkan dengan proses pengadaan barang/ jasa tidak dapat memenuhi kriteria dalam definisi pengadaan barang/ jasa pemerintah sebagaimana tercantum dalam Perpres 54 Tahun 2010.

Data pelelangan sebagaimana digambarkan pada gambar 1 diatas jika dilakukan perbandingan dengan rencana umum pengadaan yang diumumkan melalui http://sirup.lkpp.go.id/; dapat diketahui bahwa dari nilai total pelelangan Tahun 2013 sebesar Rp. 363,2 milyar ternyata nilai Rencana Umum Pengadaan (RUP) Tahun 2013 yang diumumkan adalah sebesar Rp. 614,4 milyar. Sedangkan pada Tahun 2014, nilai total pelelangan adalah Rp. 298,4 milyar, nilai total RUP 2014 yang diumumkan adalah sebesar Rp. 336,9 milyar. Pelelangan yang dilaksanakan Tahun 2015 dengan total nilai Rp. 303,5 milyar, nilai total RUP 2015 yang diumumkan adalah sebesar Rp. 365,5 milyar. Dari perbandingan data tersebut dapat diketahui bahwa terdapat perbedaan antara rencana umum pengadaan yang diumumkan dengan realisasi pengadaan.

Terdapat empat permasalahan yang bisa menjadi penyebab perbedaan tersebut, yaitu pertama adanya ketidaksesuaian antara barang/ jasa yang direncanakan dengan prioritas kebutuhan instansi. Misalnya barang/ jasa yang dibutuhkan untuk menunjang kinerja instansi tidak tercantum dalam jumlah maupun anggaran yang memadai, sedangkan barang/ jasa lainnya tersedia melimpah. Permasalahan kedua adalah ketidaksesuaian antara rencana umum pengadaan dengan anggaran yang terdapat dalam RKA-KL (Rencana Kerja dan Anggaran Kementerian/Lembaga), baik ketidaksesuaian dalam hal nilai pagu anggarannya maupun ketidaksesuaian dalam hal MAK (Mata Anggaran Kegiatan).

Permasalahan ketiga adalah adanya paket-paket pengadaan yang sudah direncanakan dan diumumkan secara luas tetapi sampai dengan berakhirnya tahun anggaran paket-paket pengadaan tersebut tidak dilaksanakan. Permasalahan keempat adalah adanya paket-paket pengadaan yang tidak pernah direncanakan sebelumnya tetapi pengadaan tersebut dilaksanakan. Permasalahan-permasalahan tersebut disebabkan kurang akuratnya penyusunan perencanaan pengadaan barang/ jasa.

\section{Teori}

\subsection{Konsep Perencanaan}

Sitanggang (1999) mendefinisikan perencanaan sebagai alat atau unsur manajemen yang digunakan untuk menggerakkan dan mengarahkan organisasi untuk 
mencapai tujuan yang telah ditentukan. Perencanaan merupakan bagian yang penting dari proses yang dijalankan oleh fungsi manajemen, karena tanpa adanya perencanaan maka fungsi-fungsi lain dari manajemen tidak akan dapat berjalan dengan baik. Pada tahap perencanaan, manajemen memutuskan tujuan yang akan dicapai serta cara-cara untuk dapat mencapai tujuan tersebut.

Berdasarkan jenjang manajemen, perencanaan dapat dikelompokkan menjadi tiga, yaitu: pertama, Perencanaan jenjang manajemen puncak yang bersifat perencanaan strategis. Perencanaan ini bersifat umum untuk jangka waktu yang panjang, didalamnya terdapat visi-misi serta tujuan organisasi. Penanggung jawab dari perencanaan ini adalah pucuk pimpinan organisasi. Kedua, perencanaan pada jenjang manajemen menengah yang bersifat perencanaan administratif atau perencanaan taktis. Perencanaan ini merupakan penjabaran dari perencanaan strategis menjadi rincian per bagian atau per unit berupa ketentuan atau prosedur serta pedoman pelaksanaan. Penanggung jawab dari perencanaan ini adalah pimpinan manajerial tingkat menengah. Ketiga, perencanaan pada jenjang manajemen bawah yang bersifat operasional berupa perencanaan prosedur, teknis pelaksanaan, dan cara-cara penggunaan sumber daya. Penanggung jawab dari perencanaan ini adalah manajer operasional atau manajer teknis.

Sedangkan Friedman dalam Tarigan (2012) menjelaskan bahwa agar perencanaan dapat diterima oleh masyarakat luas maka dalam memformulasikan perencanaan diperlukan pemikiran yang mendalam serta melibatkan banyak pihak. Oleh karena itu, dalam proses penyusunan perencanaan diperlukan keterlibatan para pemangku kepentingan. Hal tersebut dilakukan agar mendapatkan masukan yang dapat mengakomodasikan berbagai kepentingan para pemangku kepentingan tersebut.

\subsection{Konsep Implementasi}

Rencana bukanlah merupakan tujuan akhir dari proses perencanaan. Perencanaan tidak ada manfaatnya jika tidak diikuti dengan aktifitas untuk mewujudkan apa saja yang direncanakan tersebut. Proses mewujudkan sesuatu yang sudah direncanakan untuk mencapai tujuan organisasi disebut sebagai implementasi.

Pressman \& Wildavsky dalam Conyers \& Hills (1990) menjelaskan bahwa implementasi merupakan proses interaksi antara penetapan tujuan dengan aktifitas yang diarahkan untuk mencapai tujuan. Meskipun perencanaan merupakan kegiatan yang terpisah dengan implementasi, akan tetapi pola pikir dari kedua hal tersebut harus seiring. Perencanaan dan implementasi merupakan bagian dari siklus "Planning Process" yang tidak dapat dipisahkan.

\subsection{Pengadaan Barang/Jasa Pemerintah}

Kegiatan pengadaan barang sudah berlangsung sejak jaman dahulu, dimulai dengan transaksi yang dilakukan melalui barter (pertukaran barang dengan barang) sampai dengan saat ini dimana transaksi dilakukan dengan uang. Pada perkembangannya, transaksi tidak hanya dilakukan terhadap barang tetapi dilakukan juga terhadap jasa. Obyek dari proses pengadaan dapat berupa barang berwujud (tangible) maupun barang tidak berwujud (intangible).

Pengadaan barang/ jasa ditinjau dari subyeknya terdiri dari pengadaan barang/ jasa yang dilakukan oleh swasta atau sektor privat dan pengadaan barang/ jasa yang dilakukan oleh pemerintah. Jika ditinjau dari obyeknya, pengadaan barang/ jasa terdiri dari pengadaan barang/ jasa untuk keperluan publik dan pengadaan barang/ jasa untuk keperluan privat. Sedangkan ditinjau dari sumber pendanaannya, pengadaan barang/ jasa dapat bersumber dari dana pemerintah serta dapat bersumber dari dana non pemerintah.

Dari perspektif pemerintah, pengadaan barang dan jasa merupakan bagian dari pengelolaan barang milik negara. Sebagaimana tercantum dalam Peraturan Pemerintah Nomor 27 Tahun 2004 tentang Pengelolaan Barang Milik Negara/ Daerah pasal 3 ayat (2) disebutkan bahwa Pengelolaan Barang Milik Negara/ Daerah meliputi: perencanaan kebutuhan dan penganggaran, pengadaan, penggunaan, pemanfaatan, pengamanan dan pemeliharaan, penilaian, pemindahtanganan, pemusnahan, penghapusan, penatausahaan, pembinaan, pengawasan, dan pengendalian. Definisi barang milik negara menurut Peraturan Pemerintah Nomor 27 Tahun 2004 pasal 1 angka 1 adalah semua barang yang dibeli atau diperoleh atas beban anggaran pendapatan dan belanja negara atau berasal dari perolehan lainnya yang sah.

\subsection{Penelitian Terdahulu}

Iskandar (2013) melakukan penelitian dengan cara melakukan analisis kinerja pengadaan barang/ jasa pemerintah dengan membandingkan konsep pengadaan yang ideal sesuai dengan prinsip-prinsip pengadaan sebagaimana diatur dalam Peraturan Presiden Nomor 54 Tahun 2010 dengan penerapannya. Metode penelitian yang digunakan dalam penelitian yang berjudul "Analisis Pengadaan Barang/ Jasa di Pemerintah Kota Sukabumi, Pemerintah Kota Bogor, dan Lembaga Kebijakan Pengadaan Barang/ Jasa Pemerintah (LKPP)"; adalah metode gabungan kualitatif dan kuantitatif dengan pendekatan analisis deskriptif. Hasil dari penelitian ini adalah berupa rekomendasi kebijakan apa saja yang harus dilakukan untuk menghasilkan pengadaan pengadaan barang/ jasa yang lebih kredibel dan berintegritas. Hasil penelitian menunjukkan bahwa 
meskipun dapat menghasilkan efisiensi tetapi masih ditemukan hal-hal yang tidak sesuai dengan prinsipprinsip pengadaan serta kinerja pengadaan masih harus ditingkatkan.

Sementara itu, Purtanto (2015) dalam tesis yang berjudul Faktor-faktor yang Mempengaruhi Penyerapan Anggaran Belanja Pemerintah Daerah: Proses Pengadaan Barang/ Jasa Pemerintah; menyimpulkan bahwa komitmen manajemen dan perencanaan berpengaruh positif dan signifikan terhadap penyerapan anggaran pengadaan barang/ jasa. Monitoring dan evaluasi berpengaruh positif namun kurang signifikan, kompetensi sumber daya manusia tidak berpengaruh positif, dan pengaruh lingkungan eksternal kurang signifikan terhadap penyerapan anggaran pengadaan barang/ jasa. Penelitian tersebut menggunakan metode penelitian kuantitatif dengan regresi berganda. Tujuan dari penelitian ini adalah untuk menguji komitmen manajemen, perencanaan, kompetensi sumber daya manusia, monitoring dan evaluasi, dan lingkungan eksternal terhadap penyerapan anggaran terkait pengadaan barang/ jasa.

Adapun Sukarmei (2011) dalam tesis yang berjudul "Pengaruh Metode Evaluasi Penawaran Pengadaan Barang/Jasa Pemerintah terhadap Hasil Pekerjaan Dengan Pendekatan Analytical Hierarchy Process (Studi Kasus di Pemerintah Kabupaten Temanggung)"; menyebutkan bahwa sistem gugur dan sistem nilai (daftar simak dan passing gradel ambang lulus) berbeda karakteristiknya dalam hal waktu evaluasi; biaya evaluasi, hasil evaluasi, keterperincian, persyaratan; ketepatan memilih penyedia jasa; hasil pedoman pelaksanaan di lapangan; pendapat penyedia jasa; hasil pekerjaan, seleksi peserta, penentuan pemenang, jumlah temuan pemeriksa, pendapat pengguna anggaran, PPK, panitia pengadaan barang/ jasa dan batasan evaluasi. Sedangkan yang terbesar terdapat pada biaya evaluasi. Hasil validasi data menunjukkan bahwa sistem nilai masih mengedepankan faktor kemampuan finansial, pengalaman perusahaan, personil tenaga ahli minimal dan peralatan kerja minimal yang harus di miliki pelaksana pekerjaan/ penyedia barang atau jasa.

Sedangkan menurut Higgins dalam Salusu (2006) implementasi merupakan rangkuman dari berbagai aktifitas yang melibatkan sumber daya manusia dengan menggunakan sumber daya lain untuk sasaran dari strategi. Aktifitas tersebut melibatkan semua jenjang manajemen mulai dari pucuk pimpinan hingga karyawan pada jenjang paling bawah. Dapat dikatakan bahwa implementasi merupakan sebuah proses yang terarah dan terkoordinasi dengan melibatkan banyak sumber daya.

\section{Metode Penelitian}

\subsection{Sosial Setting Universitas Brawijaya}

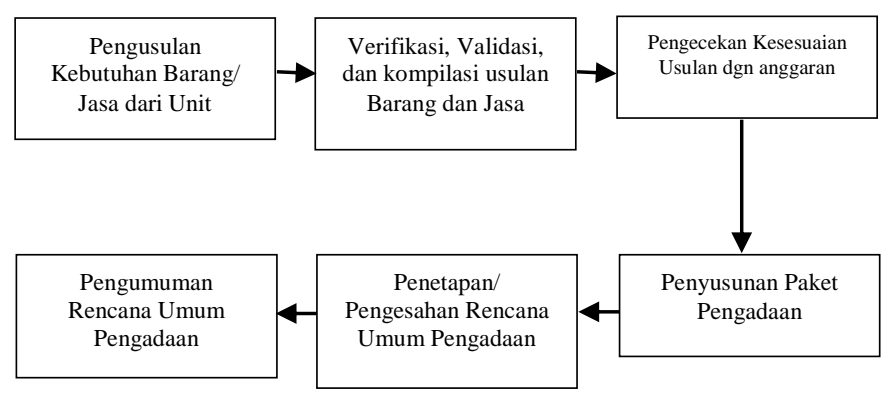

Gambar 2 Alur Proses Penyusunan Perencanaan Umum Pengadaan Barang/ Jasa di Universitas Brawijaya

Sumber: Hasil analisis, 2018

Gambaran tentang alur proses penyusunan perencanaan umum pengadaan barang/ jasa di Universitas Brawijaya, maka digambarkan diagram alur sebagai berikut:

Unit Kerja sebagai pengguna barang/ jasa yang mengajukan usulan kebutuhan barang/ jasa. Unit Kerja yang dimaksud bisa dari Laboratorium Sentral, Fakultas, Badan Pengelola Usaha, Lembaga, dan Unit lain yang tercantum dalam Susunan Organisasi dan Tata Kerja Universitas Brawijaya (SOTK UB) berdasarkan Peraturan Rektor Universitas Brawijaya Nomor 20 Tahun 2016. Sub Bagian Perencanaan yang melakukan verifikasi, validasi, dan kompilasi terhadap usulan kebutuhan barang/ jasa yang disampaikan oleh seluruh Unit Kerja. Selanjutnya melakukan pengecekan kesesuaian usulan pengadaan barang/ jasa dengan anggaran yang tersedia melalui aplikasi SiReKA (Sistem Rencana Kegiatan dan Anggaran). Rektor selaku Kuasa Pengguna Anggaran mengesahkan Rencana Umum Pengadaan, kemudian memerintahkan operator aplikasi SiRUP (Sistem Informasi Rencana Umum Pengadaan) untuk diumumkan secara luas.

\subsection{Pendekatan dan Jenis Penelitian}

Penelitian diselenggarakan untuk menemukan pengetahuan baru. Melalui penelitian dapat ditemukan jawaban terhadap pertanyaan-pertanyaan mengenai persoalan tertentu. Tata cara bagaimana suatu penelitian akan diselenggarakan ditentukan melalui metode penelitian tertentu, antara lain metode penelitian kuantitatif, metode penelitian kualitatif, maupun gabungan metode penelitian kuantitatif dan kualitatif.

Metode penelitian kuantitatif dapat diartikan sebagai metode penelitian yang berlandaskan pada filsafat 
positivisme, digunakan untuk meneliti pada populasi atau sampel tertentu. Teknik pengambilan sampel pada umumnya dilakukan secara random, pengumpulan data menggunakan instrumen penelitian, analisis data bersifat kuantitatif/ statistik dengan tujuan untuk menguji hipotesis yang telah ditetapkan (Sugiyono, 2012).

Sedangkan metode kualitatif merupakan tradisi tertentu dalam ilmu pengetahuan sosial yang secara fundamental bergantung pada pengamatan terhadap manusia dalam kawasanya sendiri dan berhubungan dengan orang-orang tersebut dalam bahasanya dan dalam peristilahanya. Metode kualitatif sebagai prosedur penelitian yang menghasilkan data deskriptif berupa kata-kata atau lisan dari orang-orang dan perilaku yang dapat diamati dikemukakan oleh Bogdan dan Taylor (1975) dalam Moleong (2004).

Miles dan Huberman menyebutkan bahwa metode kualitatif berusaha mengungkap berbagai keunikan hasil observasi yang terdapat dalam individu, kelompok, masyarakat, dan/ atau organisasi dalam kehidupan seharihari secara menyeluruh, rinci, dalam, dan dapat dipertanggungjawabkan secara ilmiah (Miles \& Huberman, 1994) dalam Sukidin (2002).

Sebagaimana disebutkan dalam rumusan masalah pada bagian pendahuluan, penelitian ini berusaha mengungkapkan permasalahan-permasalahan yang terjadi dalam perencanaan pengadaan barang/ jasa pada Universitas Brawijaya. Untuk mendapatkan jawaban atas permasalahan tersebut penulis menggunakan pendekatan penelitian kualitatif.

\subsection{Studi Kasus}

Pada umumnya, penelitian dalam bidang ilmu-ilmu sosial menggunakan metode penelitian eksperimen, survei, historis, dan analisis informasi. Selain itu, dapat juga menggunakan studi kasus sebagai strategi dalam menyelenggarakan penelitian. Masing-masing metode memiliki keunggulan dan kelemahan tersendiri. Pemilihan metode yang lebih sesuai untuk penelitian didasarkan pada pertimbangan: a) Jenis atau tipe pertanyaan penelitian; b) Seberapa besar kemampuan peneliti melakukan kontrol terhadap peristiwa perilaku yang akan diteliti; serta c) Fokus penelitian terhadap fenomena penelitian, apakah fenomena kontemporer (masa kini) ataukah fenomena historis (sejarah/ masa lalu). Menurut Yin (2012), penggunaan strategi studi kasus dalam suatu penelitian lebih sesuai jika tipe pertanyaan penelitian adalah ' $h o w$ ' atau ' $w h y$ ', kemudian peneliti memiliki sedikit peluang untuk melakukan kontrol terhadap peristiwa-peristiwa yang akan diteliti, dan jika fokus penelitian terletak pada fenomena kontemporer didalam konteks kehidupan nyata.

\subsection{Lokasi Penelitian}

Universitas Brawijaya adalah lokasi penelitian dengan beberapa pertimbangan. Lingkungan perguruan tinggi merupakan fokus yang dipelajari pada program studi Magister Manajemen Pendidikan Tinggi. Peneliti saat ini bekerja di Universitas Brawijaya dibidang pengadaan barang/ jasa pemerintah, sehingga peneliti terlibat langsung dalam permasalahan yang menjadi fokus pada penelitian ini. Sebagaimana dijelaskan pada Latar Belakang, Universitas Brawijaya memiliki anggaran pengadaan barang/ jasa yang sangat besar.

\subsection{Fokus Penelitian}

Menurut Moleong (2004), fokus penelitian dimaksudkan untuk membatasi penelitian guna memilih mana data yang relevan dan yang tidak relevan. Sedangkan perumusan fokus masalah dalam penelitian kualitatif bersifat tentatif, artinya penyempurnaan rumusan fokus atau masalah masih tetap di lakukan sewaktu penelitian sudah berada dilapangan.

Dalam penelitian ini, fokus penelitian yang ditetapkan oleh peneliti adalah evaluasi terhadap pelaksanaan perencanaan umum pengadaan barang/ jasa pemerintah di Universitas Brawijaya. Dalam evaluasi ini penekanan dilakukan terhadap proses implementasi kebijakan pemerintah tentang rencana umum pengadaan, yaitu dengan membandingkan kesesuaian pelaksanaan rencana umum Pengadaan di Universitas Brawijaya dengan pedoman penyusunan rencana umum Pengadaan yang telah ditetapkan oleh pemerintah.

\subsection{Analisis Data}

Model analisis yang digunakan adalah model analisis interaktif, yaitu berupa langkah-langkah: pengumpulan data, penyajian data, penarikan kesimpulan, dan reduksi data. Miles, Huberman, dan Saldana (2014) berpendapat bahwa analisis terdiri dari tiga alur kegiatan yang terjadi secara bersamaan, yaitu: reduksi data, penyajian data, dan penarikan kesimpulan atau verifikasi.

Komponen-komponen analisis data model interaktif mengandung tiga segmen, yaitu (a) kondensasi data, (b) penyajian data, dan (c) kesimpulan atau verifikasi.

\subsection{Validitas Data}

Untuk mendapatkan keabsahan data dalam penelitian kualitatif, digunakan teknik triangulasi. Menurut Denzin \& Lincoln (2011) triangulasi berfungsi sebagai sebuah proses penggunaan berbagai persepsi untuk memperjelas makna dengan cara-cara yang berbeda dalam memandang kasus. 
Teknik Triangulasi terdiri dari empat macam, yaitu: (a) Triangulasi sumber data, (b) Triangulasi metode, (c) Triangulasi teori, dan (d) Triangulasi peneliti. Dari keempat jenis triangulasi tersebut, peneliti memilih untuk menggunakan triangulasi multi sumber melalui beberapa sumber data yang dikumpulkan menggunakan metode wawancara, observasi, dan dokumentasi.

\section{Hasil Penelitian dan Pembahasan}

\subsection{Penyusunan Rencana Umum Pengadaan Barang/ Jasa Pemerintah Universitas Brawijaya}

Universitas Brawijaya, salah satu kampus PTN di Malang yang memiliki jumlah mahasiswa terbanyak di Malang, memerlukan fasilitas sarana prasarana yang memadai, tata kelola, infrastruktur, dan lain sebagainya demi menunjang keberhasilan dan kemajuan pendidikan. Diperlukan perencanaan yang matang agar menghasilkan sarana-prasarana yang memenuhi kebutuhan para pemangku kepentingan. Untuk dapat melakukan penyusunan rencana dan pelaksanaan pengadaan yang matang diperlukan personil yang profesional dibidangnya. Personil yang berprofesi di bidang pengadaan barang/ jasa menduduki jabatan fungsional tertentu.

Pejabat Fungsional Pengelola Pengadaan Barang/ Jasa Pemerintah adalah jabatan yang mempunyai ruang lingkup tugas, tanggung jawab dan wewenang untuk melakukan kegiatan pengadaan barang/ jasa pemerintah sesuai dengan peraturan perundang-undangan. Sedangkan pelaksanaan pengadaan barang/ jasa pemerintah adalah kegiatan untuk memperoleh barang/jasa oleh kementerian/lembaga/ pengadaan barang/ jasa pemerintah daerah/ institusi yang prosesnya dimulai dari perencanaan kebutuhan sampai dengan diselesaikannya seluruh kegiatan untuk memperoleh barang/ jasa. Untuk mewujudkan pegadaan barang/ jasa pemerintah yang efektif, efisien, terbuka, transparan, adil dan kompetitif akuntabel kompetitif pemerintah mengeluarkan peraturan Presiden No 54 Tahun 2010 tentang pengadaan barang/jasa pemerintah yang terakhir diubah melalui Perpres No 4 Tahun 2015.

Adanya Perpres ini bisa dijadikan pedoman dalam pelaksanaan pengadaan barang/ jasa pemerintah, baik yang dibiayai APBN dan/ atau APBD. Selain untuk mencapai tujuan yang efektif dan efisien, adanya peraturan dan kebijakan pemerintah ini dapat dijadikan dasar dalam memenuhi prinsip persaingan yang sehat, transparan, terbuka, dan perlakuan yang adil bagi semua pihak.

Fokus utama perencanaan sebagaimana hasil dari wawancara dengan Bapak Syarif Utomo selaku Kepala Biro Umum dan Kepegawaian Universitas Brawijaya adalah sebagai berikut:

"Implementasi Perencanaan kebijakan dalam hal pengadaan barang/jasa di Universitas Brawijaya diwujudkan dalam beberapa hal antara lain: Penyusunan rencana umum pengadaan barang/ jasa dilakukan sebelum tahun berjalan dan diumumkan secara luas melalui SiRUP lkpp.go.id" (Senin, 11 Juni 2018: 09.18 WIB) .

Pelaksanaan pemilihan penyedia dilakukan oleh Pokja Unit Layanan Pengadaan (ULP) melalui Aplikasi Sistem Pengadaan Secara Elektronik (SPSE). Pengadaan barang yang terdapat di e-Katalog dilaksanakan secara ePurchasing. Sejalan dengan hal ini, untuk meningkatkan Kapasitas Sumber Daya Manusia (SDM) dalam pengadaan barang/ jasa di Universitas Brawijaya, bagian pengadaan dan ULP juga membekali SDM yang ada dengan mengadakan pelatihan pengadaan barang/ jasa.

Sebelum melaksanakan tugas implementasi kebijakan pengadaan barang/ jasa membuat perencanaan terlebih dahulu yang disusun berupa Rencana Umum Pengadaan barang/ jasa (RUP). RUP ini bisa diakses melalui laman sirup.lkpp.go.id. Agar perencanaan pengadaan barang/ jasa mendapatkan persetujuan dari pimpinan, maka dalam menyusun draft rencana pengadaan dilakukan pembahasan yang melibatkan unit pengguna barang/ jasa serta dikonsultasikan dengan pimpinan. Dan jika dalam melaksanakan tugas adanya ketidak sesuaian antara yang ada dengan perencanaan dengan tujuan yang diharapkan maka rencana umum pengadaan secara periodik dilakukan evaluasi terhadap kesesuaian antara pelaksanaan dengan perencanaan, jika ditemukan ketidaksesuaian maka akan segera dikoordinasikan dan dilakukan penyesuaian serta langkah- langkah perbaikan.

Berdasarkan pengalaman dari peneliti dan ditegaskan pula oleh Kepala Biro Umum Kepegawaian di Universitas Brawijaya sering terjadi ketidaksesuaian antara perencanaan dengan implementasi dilapangan. Untuk menyelesaikan ketidaksesuaian ini, maka pimpinan akan segera memanggil pihak terkait untuk membahas penyebab permasalahan dan mencari solusinya.

Senada dengan penjelasan diatas, wawancara yang dilakukan dengan Bapak Heri Prawoto selaku Kasubbag Perencanaan Pengadaan barang/ jasa Universitas Brawijaya memberikan penjelasan sebagai berikut:

"Penyusunan rencana umum pengadaan dilakukan dengan melibatkan unit-unit selaku pengguna barang/ jasa serta dikonsultasikan ke Rektor selaku kuasa pengguna anggaran, sedangkan prosedur tahapan dalam pemrosesan rencana umum pengadaan barang/ jasa dimulai dari penghimpunan usulan dari unit-unit, usulan pengadaan tersebut kemudian di kompilasi dan dilakukan penyusunan skala proritas dengan mempertimbangkan pagu anggaran pengadaan dari masing-masing unit. Berikutnya dilakukan konsultasi dengan pimpinan untuk mengakomodasi kebijakan pimpinan. Selanjutnya usulan pengadaan barang/ jasa tersebut 
disusun dalam format renacana umum pengadaan untuk diajukan pengesahan pimpinan. Terakhir rencana umum pengadaan yang telah disahkan oleh pimpinan akan dimasukkan oleh operator ke sistem rencana umum pengadaan (sirup.lkpp.go.id) untuk diumumkan secara luas" (Rabu, 6 Mei 2018: 14.40 WIB).

\subsection{Implementasi Rencana Umum Pengadaan Barang/ Jasa Pemerintah pada Universitas Brawijaya}

Implementasi Kebijakan tentang pengadaan barang/ jasa pada Universitas Brawijaya didasari oleh peraturan pemerintah sebagaimana hasil wawancara yang dilakukan dengan Bapak Syarif Utomo, MM selaku Kepala Biro Umum dan Kepegawaian, tentang sumber dana dalam pengadaan barang/ jasa di Universitas Brawijaya adalah DIPA BLU yang merupakan bagian dari Anggaran dan Belanja Negara (APBN). Implementasi ini sesuai dengan Perpres Nomor 54 Tahun 2010 sebagaimana terakhir diubah melalui Perpres Nomor 4 Tahun 2015.

Dalam Perpres No 4 Tahun 2015 tersebut dijelaskan bahwa pengadaan barang/ jasa wajib memenuhi prinsip efisien, artinya bahwa dengan dana dan daya terbatas dapat dicapai sasaran yang ditetapkan dengan waktu yang singkat dan bisa dipertanggungjawabkan. Selain itu prinsip kedua efektif, artinya pengadaan barang/ jasa yang ditetapkan harus dapat memberikan manfaat sebesar-besarnya. Ketiga terbuka dan bersaing, artinya bahwa dalam pengadaan barang/ jasa harus terbuka bagi yang memenuhi syarat dan dilakukan dengan persaingan yang sehat dan transparan. Keempat, yaitu transparan, artinya bahwa tata cara, evaluasi dan penetapan calon penyedia barang/ jasa bersifat terbuka bagi masyarakat luas. Kelima adil atau tidak diskriminatif, artinya perlakuan yang sama bagi semua calon penyedia barang/ jasa, dan keenam akuntabel artinya dapat mencapai sasaran baik fisik, keuangan maupun manfaat bagi pelaksana tugas pemerintahan dan pelayanan masyarakat.

Wawancara yang dilakukan dengan Bapak Edy Sunandar selaku operator Sistem Informasi Rencana Umum Pengadaan (SIRUP) menjelaskan bahwa Prosedur/ tahapan dalam menginputkan RUP ke SIRUP sebagai berikut: Pertama, Operator Sirup menerima dokumen RUP yang sudah disahkan oleh kuasa pengguna anggaran (KPA), Kemudian Operator SIRUP akan berkonsultasi dengan bagian keuangan untuk memastikan bahwa kode Mata Anggaran Keuangan (MAK) sesuai dengan dokumen Rencana Kerja Anggaran Kementrian/ Lembaga (RKA-KL), berikutnya operator akan login menggunakan akun admin-rup di laman http://sirup.lkpp.go.id dan menginputkan data RUP tersebut ke SIRUP. Tahap akhir adalah mengumumkan RUP yang sudah diinputkan di SIRUP melalui akun ub_kpa.
Sedangkan untuk memastikan bahwa data RUP yang diinputkan ke SIRUP sudah sesuai atau belum, maka pemrosesan RUP dilakukan dengan dua cara: Pertama diproses secara offline menggunakan program aplikasi Microsoft Excell. Kemudian yang kedua, baru diinputkan ke aplikasi SIRUP.

\subsection{Evaluasi Rencana Umum Pengadaan Barang/Jasa Pemerintah pada Universitas Brawijaya}

Pelaksanaan instrumen implementasi hasil evaluasi kebijakan perencanaan umum pengadaan barang/ jasa pemerintah pada Universitas Brawijaya dilakukan pada saat proses pelaksanaan pengadaan barang/ jasa dan dapat juga dilaksanakan setelah selesainya proses pelaksanaan pengadaan barang/ jasa tersebut. Dalam hal ini, audit pengadaan dilakukan oleh pengguna barang/ jasa, Aparat Pengawas Intern Pemerintah (APIP), dan Auditor eksternal pemerintah (BPK-RI) baik melalui audit keuangan, audit kinerja atau audit investigasi.

Audit keuangan adalah audit yang dilakukan untuk menguji apakah laporan keuangan sudah sesuai prinsip akuntansi. Menurut Pernyataan Standar Audit (PSA) Nomor 62 yang diterbitkan IAI menyatakan bahwa audit atas entitas pemerintah meliputi audit kepatuhan peraturan perundang-undangan dan pengendalian intern. Hal ini juga dapat dilakukan untuk melakukan audit pengadaan barang dan jasa.

Audit kinerja adalah audit yang dilakukan atas kegiatan untuk meyakinkan bahwa pelaksanaan kegiatan/ program tersebut telah dilaksanakan. Mengacu pada prinsip ekonomis, efisien, dan efektif sesuai dengan tujuan yang direncanakan dan tidak bertentangan dengan peraturan perundang-undangan yang berlaku

Keputusan Presiden Nomor 80 Tahun 2003 tentang pedoman pelaksanaan pengadaan barang/ jasa pemerintah; telah mengatur tentang prinsip dasar dalam pengadaan barang/ jasa dengan prinsip efisien, efektif, terbuka dan bersaing, transparan, adil/ tidak diskriminatif, dan akuntabel.

Adanya peraturan dapat diminimalkan bahkan bisa cegah terjadinya pelanggaran-pelanggaran yang dimungkinkan dalam pengadaan barang dan jasa dengan memperhatikan prinsip dasar tersebut. Sebagai contoh, hal umum yang sering terjadi selama ini adalah pembelian suatu barang yang harganya diatas Harga Patokan Standar (HPS). Tentunya ini tidak efisien dan melanggar prinsip pengadaan barang.

Selain itu, pengadaan barang/ jasa dikatakan tidak efektif jika dalam pengadaannya sebenarnya tidak dibutuhkan tetapi tetap dilaksanakan pengadaan. Hal ini dapat menyebabkan kerugian negara atau boros.

Pelanggaran lain yang dapat dihindari dengan adanya peraturan pemerintah ini adalah Penunjuk Langsung (PL) atau Pemilihan Langsung. 
Untuk menghindari pelaksanaan atau proses pengadaan barang/ jasa yang berindikasi korupsi, kolusi dan nepotisme (KKN) maka dilakukan audit investigasi. Jika dalam audit yang dilakukan terindikasi adanya kerugian negara, maka audit akan ditekankan kepada identifikasi pidana. Tetapi jika setelah adanya keputusan dari pengadilan bahwa yang terjadi adalah kasus perdata, maka kerugian negara harus dicegah dengan berbagai upaya hukum untuk mengembalikan aset negara.

Keputusan Presiden Nomor 80 Tahun 2003 didalam pasal 49 ayat 1 menjelaskan bahwa dalam tindak lanjut pengawasan kepada pihak yang terbukti melanggar ketentuan dan prosedur, maka dapat dikenakan sanksi administrasi, dituntut ganti rugi/ digugat secara perdata, dan dilaporan untuk diproses secara pidana. Dalam pasal ini juga dijelaskan sanksi-sanksi atas perbuatan atau tindakan penyedia barang/ jasa yang dapat dikenai sanksi.

Jika adanya ketidaksesuaian antara perencanaan dengan pelaksanan di Universitas Brawijaya adalah biasanya atasan memperingatkan agar lebih teliti dalam memproses RUP dan memeriksa ulang RUP yang sudah diinputkan di SIRUP. Adapun solusinya jika disebabkan karena kesalahan dari unit pengguna untuk memastikan RUP yang benar, jika disebabkan karena kesalahan input maka akan di revisi mengacu pada Dokumen RUP hardcopy yang sudah ditetapkan oleh kuasa Pengguna Anggaran. Sebagaimana yang dijelaskan oleh Bapak Edy Sunandar selaku Operator Sistem Informasi Rencana Umum Pengadaan (SIRUP). Faktor pendukung dalam pemrosesan RUP di Universitas Brawijaya adalah ketersediaan sarana prasarana khususnya infrastruktur berupa jaringan lokal maupun jaringan internet yang memadai.

Hasil wawancara yang dilakukan dengan Operator Sistem Informasi Rencana Umum Pengadaan (SIRUP), Edy Sunandar menjelaskan bahwa ruang lingkup terhadap penyusunan dan penetepan rencana umum pengadaan meliputi kebutuhan barang/ jasa, pemaketan pekerjaan, cara pengadaan serta rencana penganggaran pengadaan. Selain itu dalam pelaksanaan evaluasi terhadap persiapan pelaksanaan pengadaan meliputi pengadaan secara swakelola dan pengadaan melalui pemilihan penyedia barang/ jasa. Prosedur pemantauan dan evaluasi juga dilakukan oleh internal masing-masing $\mathrm{K} / \mathrm{L} / \mathrm{D} / \mathrm{I}$ melalui unit kerjanya.

\section{Kesimpulan}

Berdasarkan gambaran hasil penelitian yang dijelaskan pada bab sebelumnya, pada bab ini dikemukakan beberapa simpulan utama dan sangat mendasar terkait dengan Evaluasi Perencanaan Umum Pengadaan Barang/ Jasa Pemerintah pada Universitas Brawijaya, yaitu proses penyusunan, implementasi, dan evaluasi Rencana Umum Pengadaan. Proses penyusunan Rencana Umum Pengadaan Barang/ Jasa Pemerintah di Universitas Brawijaya dengan tahapan penetapan kebijakan umum kebutuhan barang/ jasa, identifikasi kebutuhan barang/ jasa yang dilakukan berdasarkan rencana kegiatan yang ada didalam renja $\mathrm{K} / \mathrm{L} / \mathrm{D} / \mathrm{I}$, pasokan (supply) barang/ jasa, ketersediaan barang (yang tersedia/ dimiliki), kebutuhan pekerjaan konstruksi dan kebutuhan jasa konsultasi. Implementasi Rencana Umum Pengadaan Barang/ Jasa Pemerintah di Universitas Brawijaya melingkupi persiapan pelaksanaan pengadaan swakelola dan persiapan pelaksanaan pengadaan melalui penyedia barang/ jasa.

Evaluasi kebijakan rencana umum pengadaan barang/ jasa pemerintah di Universitas Brawijaya meliputi penyusunan, persiapan dan pemantauan. Evaluasi terhadap penyusunan dan penetapan rencana umum pengadaan, yang meliputi identifikasi kebutuhan barang/ jasa, pemaketan pekerjaan, cara pengadaan serta rencana penganggaran pengadaan. Evaluasi terhadap persiapan pelaksanaan pengadaan yang meliputi pengadaan secara swakelola dan melalui pemilihan penyedia barang/ jasa.

Prosedur pemantauan dilakukan melalui pengisian daftar simak/ pertanyaan oleh masing-masing K/L/D/I guna mengetahui ketaatannya terhadap pemenuhan ketentuan dan prosedur yang ditetapkan. Evaluasi dan pelaporan dilakukan oleh internal masing-masing K/L/D/I melalui unit kerjanya, yang ditunjuk oleh PA untuk melaksanakan pemantauan dan evaluasi terhadap perencanaan pengadaan barang/jasa K/L/D/I dan menyampaikan lapporan hasil pemantauan dan evaluasi kepada PA guna mendapatkan penanganan lebih lanjut.

Dalam penelitian ini penulis melihat bahwa dalam pelaksanaan Pengadaan Barang/ Jasa Pemerintah perlu dipersiapkan secara lebih baik lagi, dengan harapan akan memberikan implikasi terhadap efisiensi dan efektifitas dalam penggunaan keuangan negara yang dibelanjakan melalui proses pengadaan barang/jasa. Sehingga pengelolaan barang/ jasa di masing-masing K/L/D/I akan menjadi lebih maksimal dalam penggunaannya.

\section{Daftar Pustaka}

Conyers, D. \& Hills, P. (1990). An Introduction to Development Planning in The Third World. John Wiley and Sons Ltd, New York.

Deming, W. Edwards. (1986). Out of the Crisis. Cambridge, Mass: Massachusetts Institute of Technology, Center for Advanced Engineering Study.

Denzin, Norman K., \& Lincoln, Yvonna S. (2011). The SAGE Handbook of Qualitative Research. Thousands Oaks, CA: SAGE Publications, Inc.

Sukarmei, Dwi. (2011). Pengaruh Metode Evaluasi Penawaran Pengadaan Barang/ Jasa Pemerintah Terhadap Hasil Pekerjaan Dengan Pendekatan 
Analiytical Process (Studi Kasus di Pemerintah Kabupaten Temanggung). Tesis, Program Pascasarjana Magister Teknik Sipil Universitas Diponegoro, Semarang.

Iskandar, A. Ika. (2013). Analisis Pengadaan Barang/ Jasa di Pemerintah Kota Sukabumi, Pemerintah Kota Bogor, dan Lembaga Kebijakan Pengadaan Barang/ Jasa Pemerintah (LKPP). Tesis, Fakultas Ekonomi Program Studi Magister Perencanaan dan Kebijakan Publik, Universitas Indonesia, Jakarta.

Miles, Metthew B., A. Michael Huberman., \& Johnny Saldana. (2014). Qualitative Data Analysis: A Methods Sourcebook, Third Edition. USA: Sage Publications, Inc.

Moleong, Lexy J. (2004). Metodologi Penelitian Kualitatif. Bandung: Remaja Rosdakarya.

Purtanto. (2015). Faktor-faktor yang Mempengaruhi Penyerapan Anggaran Belanja Pemerintah Daerah: Proses Pengadaan Barang/ Jasa Pemerintah (Studi atas Persepsi pada Pegawai Bersertifikat Pengadaan Barang/ Jasa di Pemerintah Kota Tegal). Tesis, Pascasarjana Program Studi Akuntansi, Universitas Sebelas Maret, Surakarta.

Salusu, J. (2006). Pengambilan Keputusan Strategik untuk Organisasi Publik dan Organisasi Nonprofit. Jakarta: PT Gramedia Widiasarana Indonesia.

Sitanggang, H. (1999). Perencanaan Pembangunan, Suatu Teori dan Praktik. PT Penebar Swadaya, Jakarta.

Sugiyono. (2012). Metode Penelitian Pendidikan (Pendekatan Kuantitatif, Kualitatif, dan R\&D). Bandung: Alfabeta.

Tarigan, R. (2012). Perencanaan Pembangunan Wilayah. Bumi Aksara, Jakarta.

Yin, R.K. (1996). Studi Kasus: Desain dan Metode. Jakarta: Raja Grafindo Persada. 